\title{
Bye Bye Bolitho? The Curious Case of the Medical Innovation Bill
}

\section{ACCEPTED FOR PUBLICATION BY MEDICAL LAW \\ INTERNATIONAL}

\section{Introduction}

Medical innovation is undoubtedly both vital and worthy of support. The position of patients with rare diseases, however, presents a specific difficulty in that there may be too few sufferers to allow clinical trials to take place. How, then, should the law encourage innovation for such patients? How might it balance this with a need to protect them? The Medical Innovation Bill (MIB) was conceived and promoted by Lord Saatchi to help such patients. In his view, the medical profession was failing to develop new treatments to combat illnesses such as the cancer that resulted in the death of his wife. As he noted in the House of Lords,

those condemned by cancer suffer a worse fate than the worst mass murderer. While they await execution, they are tortured. For them, hair loss is the good news. Less good news is that their treatment regime- the drugs and the cycles of their administration, and the surgical procedures - are often 40 years old. They create the same symptoms as the disease: nausea, diarrhoea, vomiting and fatigue. A beautiful woman's legs turn into elephant's legs; her arms begin to make a heroin addict's arms look attractive; and her bosoms turn into raisins. That is before the bad news: the discovery that standard cancer treatment does such damage to the immune system that the cancer patient is 
quite likely to die from fatal infections such as MRSA, E. coli and so on. ${ }^{1}$

The principal barrier he perceived to the development of new treatments was that to deviate from 'standard treatment' was to invite litigation, and that doctors could thus not innovate because they feared being sued for doing so. ${ }^{2}$ He therefore determined to remove the possibility of litigation in order to, hopefully, facilitate a cure for cancer. ${ }^{3}$ It should be emphasised at this point that this was the only perceived barrier to innovation identified by the Bill, and thus the only problem that it seeks to 'cure'. He assembled a team including a campaign manager and a parliamentary draughtsman to design and promote the legislation. ${ }^{4}$ This included a website, ${ }^{5}$ Twitter account, ${ }^{6}$ Facebook page, ${ }^{7}$ Tumblr page, ${ }^{8}$ and a nominated 'media partner' in the form of the Daily Telegraph ${ }^{9}$ which published a number of articles written by Lord Saatchi and his campaign team, and maintains a distinct section of their website for promotion of the Bill. $^{10}$

The MIB has caused much controversy. A Department of Health consultation produced largely negative feedback from key stakeholders, and on-going opposition has been voiced by medical bodies, research bodies, medical defence organisations and patient groups. ${ }^{11}$ This author is part of 'a small band of concerned citizens' who have our own website to campaign against the MIB. ${ }^{12}$ Despite this widespread opposition, the government has lent the Bill its support, and its passage has become a 'PR war'. ${ }^{13}$

The Bill passed the House of Lords in January 2015, but ran out of time in the House of Commons before the general election in May 2015. ${ }^{14}$ However, it is now back and 
was returned to the House of Lords in June 2015. ${ }^{15}$ If it gets back to the House of Commons, it may well become law, given that it enjoys government support. ${ }^{16}$ Meanwhile a new Bill, the Access to Medical Treatments (Innovation) Bill (AMTIB), has also been tabled by Chris Heaton-Harris in the House of Commons. It is due to be debated in October. While the MIB website claims that the AMTIB is essentially the same Bill, Lord Saatchi's Bill has not been formally withdrawn at the time of writing. ${ }^{17}$ We can only therefore conclude that the MIB is not dead and will either proceed as the AMTIB in the Commons, as the MIB in the House of Lords or even both. Yet the proposed legislation is deeply flawed. To begin with, and as I demonstrate below, no evidence has yet been presented that a fear of litigation is indeed a barrier to innovation by doctors. This removes the entire premise of the MIB. Furthermore, its actual content is not as it has been presented, and its patient safety framework is both a significant downgrade on the current law and inadequate. It is internally inconsistent and cannot function, even on its own terms. For these reasons and more I argue here that the MIB should not become law. The next section describes the Bill itself, before the article continues by assessing its shortcomings.

\section{The Medical Innovation Bill}

\subsection{What the Bill Actually Does}

The MIB, as currently drafted, is actually a rather simple Bill that seeks in a straightforward manner to solve a single, equally straightforward, problem. As 
mentioned above, after his wife died of cancer Lord Saatchi identified a fear of litigation as the barrier to more innovative treatments being developed and used by specialist doctors. The fundamental premise of the Bill is therefore that the fear of litigation must be removed from doctors, while appropriate safeguards for patients are maintained. As the Bill puts it, its purpose is to 'encourage responsible innovation' ${ }^{18}$ Thus, the MIB provides that a doctor who departs from the accepted range of treatments (which constitutes its definition of 'innovation') in a 'responsible' manner is 'not negligent'. ${ }^{19}$ Given that it therefore provides blanket immunity to such doctors, the key to the Bill lies in its definition of what constitutes 'responsible' innovation. Section 1(3) sets out the criteria that a doctor must comply with:

(a) obtain the views of one or more appropriately qualified doctors in relation to the proposed treatment,

(b) take full account of the views obtained under paragraph (a) (and do so in a way in which any responsible doctor would be expected to take account of such views),

(c) obtain any consents required by law to the carrying out of the proposed treatment,

(d) consider-

(i) any opinions or requests expressed by or in relation to the patient, 
(ii) the risks and benefits that are, or can reasonably be expected to be, associated with the proposed treatment, the treatments that fall within the existing range of accepted medical treatments for the condition, and not carrying out any of those treatments, and

(iii) any other matter that it is necessary for the doctor to consider in order to reach a clinical judgment,

(e) comply with any professional requirements as to registration of the treatment under the provisions of this Act with a scheme for capturing the results of innovative treatment (including positive and negative results and information about small-scale treatments and patients' experiences), and

(f) take such other steps as are necessary to secure that the decision is made in a way which is accountable and transparent.

Sections 1(3)(a) and (b) therefore require the doctor to consult others, and to take their opinions into account. The consultees must have 'appropriate expertise and experience in dealing with patients with the condition in question'. ${ }^{20}$ Section $1(3)(d)$ then provides some factors for the doctor herself to consider, including the patient's views and the risks and benefits associated with the proposed treatment as well as those of the standard treatments. There is also a need to comply with any professional requirement for the registration of the treatment (under s.1(3)(e)), which I consider in more detail below. 
This definition of 'responsible' innovation is also meant to provide the backbone of the safeguards for patients. If s.1(3) is not complied with, then the doctor will not enjoy the protection of the Bill. If it is, however, then the innovative treatment must be classed as 'responsible' and therefore 'not negligent' under s.1(2). In such circumstances, it is clear that it is intended that it should be impossible for a court to review the content of a decision to innovate that is covered by the Bill. ${ }^{21}$ This intent is made explicitly clear on the Bill's promotional website. ${ }^{22}$ Thus, it is important to be clear about how the MIB is designed to function. In essence, it imposes a set of conditions for doctors to negotiate and, if they do so, they are then protected from any action in negligence. As the guidance notes to a previous version of the Bill state, this reflects the 'policy intent' to bring the question of legal liability forward so that it is determined before treatment rather than retrospectively, as the current law demands. ${ }^{23}$ The purpose is to remove the fear of litigation from doctors, thus encouraging more innovative practice.

We should also pause at this point to clarify not just what the Bill does, but also what it does not do. This is particularly important given some of the claims made on behalf of the MIB which, as I discuss below, far exceed what it is able to provide. Therefore, the Bill does not give doctors access to any drugs or medication that they cannot currently access. Nor does it allow doctors to use any unlicenced drugs that they are not currently allowed to use. It does not provide any additional funding for innovative treatment or access to drugs. Indeed, the MIB does not permit doctors to do anything at all beyond what they can already do. The only thing that it does is prevent the patient from being able to sue if the doctor complies with the process outlined in the Bill and the patient is injured. In this regard, it is not a Bill that gives patients any 
'rights'. Instead it removes those rights in return for a hope that doctors, unencumbered by the fear of litigation, will innovate in a positive way and speed up breakthroughs in diseases such as cancer. ${ }^{24}$ This is clearly a controversial method of achieving its aim, and will not be without collateral damage. The doctor (rather than patient) centred nature of the Bill is another example of a disconnection between how it is presented and what it is in reality: it is there to protect doctors, not patients, despite being presented as being for the benefit of the latter. ${ }^{25}$

What we can therefore see with the Bill is that it is only designed to cure one single perceived problem: the fear of litigation being a barrier to doctors innovating. Given this, it is unsurprising that the only thing that the Bill does is to provide a framework for doctors that allows them to proceed with treatment safe in the knowledge that they will not be legally liable for any resulting injury to patients. This bringing forward of the question of potential legal liability goes towards the Bill's first pillar: the removal of the fear of litigation from doctors. The second pillar, safeguarding patient safety, is contained in the steps contained in s.1(3) that doctors must take to be covered by the Bill. Thus, put simply, unless the current law is a barrier to innovative practice, then the Bill will not help at all. However, this is not reflected by some of the claims made on behalf of the MIB by its supporters.

\section{Myth versus Reality}

Indeed, there is a significant distinction between what the Bill does in reality and what its supporters claim. This was highlighted in the government's response to the Department of Health's consultation on the Bill, which noted as a criticism of the Bill 
that '[s]ome of the statements made by supporters of the Bill ... were misleading but received much publicity'. ${ }^{26}$ Before examining how the Bill would function and the law that it would replace, then, it is worth first spending time looking at some of these misleading statements - which continue to this day - as they highlight important aspects of the Bill and its potential usefulness.

3.1 Myth 1: The Bill Only Applies to Rare Cancers and Other Diseases Lacking in Evidence Base

The first of these is that the MIB only applies to treatments for cancer and other rare diseases where the standard treatment is ineffective. Anyone reading any of the articles authored by Lord Saatchi or other members of the Bill team will see repeated references to cancer. Indeed, the first briefing note on the MIB was entitled 'How Can An Act of Parliament Cure Cancer?'27 The summary of the first incarnation of the Bill made this clear in bullet point fashion, when under the heading 'why do we need this Bill' it stated that:

1. All cancer deaths are wasted lives.

2. Science learns nothing from these deaths. Scientific knowledge does not advance by one centimetre

3. Scientific discovery comes to a "dead halt" at the bedside of the cancer victim.

4. Because current law requires that the deceased receive only the standard procedure - the endless repetition of a failed experiment.

5. Current law is a barrier to progress in curing cancer. 
6. Under present law, any deviation by a doctor from standard procedure is likely to result in a verdict of guilt for medical negligence.

7. Current law defines negligence as deviation from standard procedure.

8. But as innovation is deviation, non-deviation is non-innovation.

9. This is why there is no cure for cancer. ${ }^{28}$

Leaving aside for the moment the multiple errors in relation to what the law is and whether cancer treatment has evolved, it might be imagined from the above that the scope of the Bill is limited to cancer or other terminal or rare diseases where there is no standard treatment (or, indeed, hope). However, this is quite simply not the case, and the MIB applies to all conditions and diseases, from the most serious to the most trivial. The only exception is cosmetic surgery, which is specifically excluded. ${ }^{29}$

Furthermore, the MIB also contains a wide definition of 'innovative treatment', which is defined in s.1(2) as being a mere departure from accepted practice. In other words, the MIB applies to all non-standard treatments for all conditions except for standard treatments and cosmetic surgery. Nevertheless, the pretence that the Bill is reserved for rare cancers or other incurable diseases remains. For example, the Bill's own website contains a table seeking to demonstrate how the Bill will work. ${ }^{30}$ The very first graphic in the table says: '[p]atient is diagnosed with an incurable disease'. ${ }^{31}$

This is therefore not a Bill that is specifically targeted at rare cancers and incurable diseases, as it has been and continues to be sold as being. Rather, it pertains to any and every condition, no matter how trivial, apart from cosmetic surgery. It could almost not be wider in scope. 


\subsection{Myth 2: Medical Innovation is Being Hampered by Fear of the Law}

The second myth strikes at the very heart of the Bill, and is that medical innovation is indeed being stifled by a fear of litigation. This is in part based on an erroneous reading on the part of the Bill team regarding how the current law operates, which I discuss below. Nevertheless, it is such a key aspect of the Bill that it is the only perceived barrier to innovation that the Bill seeks to remedy. Unsurprisingly, then, it has repeatedly been cited as the Bill's raison d'etre, as Lord Saatchi himself stated when he launched the campaign on its behalf. ${ }^{32}$ It also continues to play a large role in the justification for the MIB. ${ }^{33}$

But is there actually any evidence of this? The consultation document speculated that '[s]ome argue that our increasingly litigious culture ... puts pressure on doctors to practise defensive medicine'. ${ }^{34}$ Two graphs, demonstrating the increase in clinical negligence claims and payouts since 2008 , are provided. ${ }^{35}$ But there is also a complete lack of context. There is thus no indication of how many, if any, of these claims related to innovative procedures, or of how much was paid out as a consequence. Therefore, there is absolutely no proof that the Bill would make any difference at all. Of even more concern is the fact that the responses to the consultation demonstrated that the vast majority of key stakeholders do not agree that fear of litigation is preventing innovation. ${ }^{36}$ For example, Cancer Research UK replied that: 
We have been unable to find evidence that fear of medical litigation is currently a barrier to innovation in cancer ... We have [also] been unable to find evidence that cases have been brought, or led to compensation, based on a competent doctor attempting to use an innovative treatment with the consent of a patient. ${ }^{37}$

The Motor Neurone Disease Association stated bluntly that 'such a problem does not exist' ${ }^{38}$ the Association of Medical Research Charities that they were 'not aware' of innovative practice being deterred, and the British Medical Association (BMA) also found 'no evidence' of this. ${ }^{39}$ Even the medical defence organisations, who would be expected to have been contacted by doctors worried about the chances of being sued if they innovate, reported no evidence. The Medical Defence Union (MDU) wrote that they are 'not aware of any evidence' that doctors were deterred by the fear of litigation from innovating, and indeed stated that their view is precisely the opposite that there $i s$ evidence that doctors are not deterred. ${ }^{40}$ The Medical Protection Society (MPS) similarly reported 'no evidence that fear of litigation is holding back innovation in medicine.' ${ }^{41}$ Perhaps most damningly the NHS Litigation Authority (NHSLA), which would have to know about doctors being sued, not only stated that they had no evidence or experience of doctors being sued for innovating, but added that they are however 'aware of innovation on the part of individual clinicians'. ${ }^{42}$ This is not an exhaustive list. ${ }^{43}$

In other words neither the doctors' trade union (the BMA) or either of the medical defence bodies (MDU and MPS), who doctors might be expected to consult first if worried about litigation, found any evidence of a fear of litigation deterring 
innovative treatment. Nor has the NHS body that would deal with such claims if they were to arise (the NHSLA). As demonstrated above, neither did the research bodies such as Cancer Research UK and the Association of Medical Research Charities. The only body mentioned by the response to the consultation as considering the fear of litigation a barrier to medical innovation is BASO, the Association for Cancer Surgery. ${ }^{44}$

The other evidence put forward in support of the premise that the law interferes where doctors have attempted innovative treatment comes from Lord Woolf, who wrote that,

what I do know about, from sitting as a judge, are the cases where doctors are sued for negligence because they have innovated in the treatment they offer, rather than following generally-accepted medical standards. ${ }^{45}$

However Anthony Barton, co-author of an influential clinical negligence book, asked Lord Woolf to substantiate this claim, particularly given that supporters of the Bill had been relying on it as justifying the need for the legislation. ${ }^{46}$ Lord Woolf declined to do so and, as reported by the Solicitor's Journal, asked Dr Barton to accept his recollection without naming cases. ${ }^{47}$ He then used a speech in the House of Lords to make reference to Barton's request, and to state that the evidence that he would provide was contained in his collection of essays and articles, The Pursuit of Justice. ${ }^{48}$ Unfortunately, he refused to elaborate on which pages of the book contained the evidence when asked to do so by Barton, and this author has also been unable to find them. ${ }^{49}$ As Luit-Drummond notes, 
considering the level of research supposedly carried out by the Saatchi camp in preparation of this Bill, one might expect them to have uncovered some evidence of a cure for cancer being halted by pesky lawyers. The camp's silence is deafening. ${ }^{50}$

Thus, it is difficult to come to any conclusion other than that there is no widespread fear of litigation preventing innovative practice. This is a serious blow to the Bill, as it would therefore be addressing a problem that does not exist. Indeed, given that fear of litigation is the only problem fixed by the Bill, this would make it entirely redundant. Moreover, as I argue below, the law itself is no barrier to innovation. If there are doctors who fail to innovate in situations where it is appropriate to do so, then surely the answer lies in educating them that this is the case, and the risk/benefit analysis carried out by the courts that I describe in section 4.1 of this paper. Certainly, the answer to misconceived fear is not to change legal rules that do not need to be changed. Rather, it must surely lie in debunking the misconceptions.

\subsection{Myth 3: The Bill Enjoys Widespread Support}

The next myth surrounding the Bill is that it enjoys widespread support from key stakeholders. The question of whether the Bill is 'wanted' can be divided into two categories. The first is the claim that it has popular support from the public, and the second is that it has the support of those who it is there to benefit - doctors and patients. In relation to sheer numbers, the Saatchi Bill team and its supporters have claimed that the proposed legislation enjoys high levels support. ${ }^{51}$ The figure most usually referred to is that over 18500 responses were received in favour of the 
legislation, with only an additional 100 reported that opposed it. ${ }^{52}$ There is some confusion over these figures, but they essentially include both the responses to the Department of Health's consultation (170 responses) and a petition organised by the Saatchi Bill team (over 18,000 responses by the close of the Department of Health's consultation). ${ }^{53}$ The Bill team attempted to use these figures to demonstrate that the response to the MIB had been unusually high, stating in their post-consultation briefing note that the Department of Health had told them that anything above 600 responses would be 'good' and contrasting that to the over 18,500 received. ${ }^{54}$ This number was frequently and continuously used to justify claims regarding the strength of feeling in support of the Bill. ${ }^{55}$ But the figure of 600 relates not to social media campaign and petitions, but the official Department of Health consultation, which only received 170 responses. This hardly demonstrates an unusually large level of interest. Moreover, this was inadvertently demonstrated by the Bill team itself in its reply to concerns expressed about the multiple channels for response. ${ }^{56}$ They provided two examples of government consultations where alternative methods of response were considered and utilised, one relating to standardisation of tobacco packaging, the other to the future of tobacco control. They received 665,989 and 96,000 responses respectively. Given this, the claim that the Bill's consultation benefits from an unusually high response cannot be supported. ${ }^{57}$

The same can be said for the notion that the Bill enjoyed 'overwhelming support' amongst key stakeholders. ${ }^{58}$ Almost as soon as the Department of Health's consultation closed, the Bill team claimed victory. As Lord Saatchi declared in the Daily Telegraph less than a week later: 
Last week, the Department of Health closed the public consultation into the Medical Innovation ... We now have the results. A staggering 18,655 people including doctors and patients, relatives of the bereaved and soon-to-be bereaved, scientists, lawyers, legislators and the man and woman in the street - have responded wholeheartedly in support of this Bill. Fewer than 100 were against it. ${ }^{59}$

By the following month, a new version of the Bill had been prepared, including a 52 page briefing note, 'following the Department of Health's consultation'. ${ }^{60}$ The Bill received its first reading in the House of Lords four days later on $5^{\text {th }}$ June $2014 .{ }^{61}$ However the results of the consultation, and the Department of Health's response, did not appear until $30^{\text {th }}$ July 2014. In other words, all of the time and expense involved in the consultation exercise were ignored as the Bill team proceeded without waiting for the results to be published and the government's analysis of them to be undertaken. Furthermore, the Department of Health's consultation was the method used by the more reflective respondents, and of course the major stakeholders and their responses will not have been available to the Bill team to consider.

In the meantime, opposition to the Bill was presented in a way that portrayed it as representing vested interests. For example Dominic Nutt, a member of the Bill team, put it in these terms in June 2014:

In favour are, broadly speaking, patients and their families, as well as many doctors. Against it are medical negligence lawyers who defend and prosecute doctors under the current law, and some medical bodies. ${ }^{62}$ 
However, this is far removed from the actual responses to the consultation of key stakeholders. Indeed the professional bodies representing doctors - who, it should be remembered, the Bill is intended to unshackle - are virtually unanimously and strongly against the Bill, and have been since the consultation. The General Medical Council (GMC) called it 'unnecessary and undesirable', while the British Medical Association's response to the consultation concluded that '[t]he BMA strongly believe that this Bill should not become law'. ${ }^{63}$ Other bodies (representing doctors, patients, regulators and researchers) who have made their responses public and are either unpersuaded by or even hostile to the Bill include the Academy of Medical Royal Colleges, Action Against Medical Accidents, the Motor Neurone Disease Association, the Patients Association, the NHS Litigation Authority, the National Institute for Health and Care Excellence, the Academy of Medical Sciences, the Medical Research Council and the Wellcome Trust. ${ }^{64}$ Perhaps even more significantly for the supporters of the Bill, both of the medical defence organisations, the MDU and MPS, also oppose it. ${ }^{65}$ Indeed, the government's response to a Freedom of Information request revealed that the majority of responses to the Department of Health's consultation were negative. ${ }^{66}$ This continues to this day, with each of the bodies mentioned above remaining opposed to the Bill, even in its current form. $^{67}$

So let us be clear about the level of support enjoyed by the Bill. Both the GMC and the BMA remain against it, and the latter in particular has been very vociferous in its opposition from the beginning. ${ }^{68}$ The same is the case with the Royal Colleges. It 
has also been opposed from the start, and continues to be so, by both of the main medical defence organisations in the form of the MDU and MPS. ${ }^{69}$ The same is the case for patient groups, such as Action Against Medical Accidents (AvMA) and the Patients' Association, who have never supported the Bill. ${ }^{70}$ Even medical research groups and charities, such as Cancer Research UK, the Wellcome Trust and the Medical Research Council, are still against it. ${ }^{71}$ Their view is exemplified by the Motor Neurone Disease Association, who say, unequivocally, that the Bill 'would be bad law. ${ }^{72}$ In other words the key stakeholders - the very people who the Bill is supposed to benefit and protect - are virtually unanimous in their opposition to the MIB. Moreover, this lack of support has been in evidence ever since the consultation and, despite all of the amendments to the Bill, none have been convinced to change their minds. Any claim that the Bill enjoys widespread support, then, cannot be substantiated.

\subsection{Myth 4: The Bill Establishes A Medical Register}

The final myth in relation to the Bill relates to the register that is claimed to accompany it. This has become an increasing focus of the Bill, and indeed the Bill's website contains an entire section on it. The claim is that:

[t]he open access Medical Innovation Register will record all treatments and their outcomes, both positive and negative, which are received by patients under the MIB. 
As the Bill leaves the House of Lords for the House of Commons on 23rd January 2015 we are thrilled that recording all treatments and their outcomes received under the Bill in the Medical Innovation Register will become a requirement. ${ }^{73}$

The idea behind the register is tied to the (as demonstrated above, inaccurate) notion that the Bill only applies to rare diseases where clinical trials are unavailable. The premise is that although there may be too few patients to warrant a clinical trial, by recording the outcomes of innovative treatments we may over time build an evidence base which, at the very least, will help future doctors to assess whether to try the same thing. ${ }^{74}$ This is not an uncontroversial idea, and indeed it has been argued that it would undermine clinical trials. ${ }^{75}$ Moreover, there are other issues with the proposed register that have not been considered or explained. Who, for example, will fund it? Lord Saatchi announced the register during the second reading of the Bill in the House of Lords in June 2014, and stated that Oxford University had agreed to host it, but nothing was said about its long term funding. ${ }^{76}$ It is said that it will be a 'public' register, but if so how will patient confidentiality be maintained if some conditions (such as Ebola) may contain details of only one patient? ${ }^{77}$ If recording the outcome in the register is compulsory, what will happen to patients who do not wish to consent to this? Will the doctor not be able to rely on the protection of the Bill, and will this therefore mean that patients may be deprived of innovative treatment if they do not agree to have their information shared on the register?

These are important questions but they do not form the focus of this section, which will concentrate on a more fundamental question, which is whether such a register is 
required by the MIB at all. In short, the Bill does not actually create or require the use of a register. The claim on the Bill website is that ' $[\mathrm{t}]$ he register will be set up only when the Bill becomes law. It cannot, and will not happen, unless the Bill is passed by MPs', ${ }^{78}$ but it does not even do this. The relevant part of the Bill (s.1(3)(e)) states that the doctor must:

comply with any professional requirements as to registration of the treatment under the provisions of this Act with a scheme for capturing the results of innovative treatment (including positive and negative results and information about small-scale treatments and patients' experiences).

The section above - quoted in its entirety - clearly does not set up any register. All that it does is demand that a doctor comply with any professional requirements for registration. This means that a register would have to be set up, and the medical regulator (which in this case would have to be the GMC) would have to create an obligation on the part of doctors to use it. Barrister Nigel Poole contacted the GMC to establish its views and, as he notes, the GMC responded that it is not in favour of establishing and policing such a register. ${ }^{79}$ He quotes the GMC stating that:

We have statutory powers to provide advice and doctors must be prepared to justify their decisions and actions against the standards set out in our guidance. Serious or persistent failure to follow the guidance will put a doctor's registration at risk. We confirmed to the Department that our initial view was that fitness to practise proceedings being brought against a doctor for not having recording information on an online database designed to foster the 
sharing of learning from innovation does not seem to be a proportionate response. ${ }^{80}$

Thus, in order for the register to exist it would need to be established separately by the GMC, along with a new policy requiring its use. The registration provisions of the Bill are therefore entirely redundant, since they merely require the doctor to follow rules they would have to follow in any event, whether the Bill reminded them to or not.

However, the GMC seems not just reluctant but actively opposed to creating and policing such a register. It is for this reason that Poole refers to the register as ' $\mathrm{a}$ chimera'. ${ }^{81}$ Moreover, contrary to the Bill team's claims, the register can exist without the Bill. This is because even the Bill envisages it being set up and maintained as a professional rather than legal obligation. In other words, if the will were there on the part of the GMC the register could be established irrespective of the MIB coming into law.

\subsection{Conclusion}

The MIB has been presented as being specifically targeted towards rare diseases, particularly cancer, solving a specific problem, enjoying widespread support and establishing a register. However, as I demonstrate above, none of this stands up to scrutiny. The MIB applies to all diseases and conditions other than cosmetic surgery. The Bill team has also failed to provide any evidence of a fear of litigation hampering innovation. Indeed, virtually all of the key stakeholders responding to the Department 
of Health's consultation stated that the law is not an impediment and that they have no evidence of such fears being expressed to them. ${ }^{82}$ While we must be wary about simply accepting the opinion of such organisations, when medical groups, patient groups, medical protection organisations and research groups all come to the same conclusion we must surely at least require some solid examples of the law intervening negatively. This has not been provided. These groups also oppose the Bill in general terms - and, again, when opposition is so ubiquitous we must question whether the MIB is fundamentally flawed. For example, as late as January 2015 the GMC, in evidence to the Health Committee, stated that it had 'still not heard a convincing argument' regarding why the Bill is necessary at all. ${ }^{83}$ Lord Saatchi's declaration, once the Bill left the House of Lords for the Commons, that '[h]onest opposition [to the Bill] ... has had their concerns met' can also thus not be supported. ${ }^{84}$ Finally, the Bill does not establish a register as it claims. Rather, it only mandates discharging any professional responsibilities that might exist to record treatments in a register. But, given that the regulator has not set up such a register and does not agree with the principle of doing so, such a professional requirement is highly unlikely to exist. This is, of course, to ignore the other issues surrounding the register that have yet to be discussed.

All of this should give us pause for thought. This is a Bill where the rhetoric does not match the reality of the provisions. Indeed, put bluntly, the Bill is based upon an emotive assertion that if only doctors were unshackled from fear of the law, there would be a cure for cancer and patients would have access to treatments that they are currently being denied. Yet the Bill team and its supporters have failed to provide any evidence of these shackles being present, or of patients currently being denied 
drugs or treatments that would otherwise be available due to a fear of litigation. It is worth repeating that the Bill does not make available anything that doctors cannot currently use. However the real dangers inherent in the Bill become evident when one considers how it will function and compare it to the law, as this is where the MIB ceases to be merely pointless and becomes an active threat to patient safety. Again, there are differences between how the Bill is presented and how it would actually operate.

\section{How Will the Bill Work?}

\subsection{The Current Law}

Before considering what the Bill proposes to do it is first necessary to explain the current legal regime that it seeks to replace. Medical and Tort lawyers will be more than familiar with the test for negligence imposed by Bolam and Bolitho, so I will consider them only briefly. ${ }^{85}$ Essentially, the law prescribes a two stage test in order to ascertain whether a doctor's conduct fell below the standard of care prescribed by the law. The first part is governed by Bolam and asks whether, in the circumstances, there is a body of medical opinion that might do as the defendant doctor did. This was, famously, expressed by McNair J in Bolam in the following way: 
A doctor is not guilty of negligence if he has acted in accordance with a practice accepted as proper by a responsible body of medical men skilled in that particular art. ${ }^{86}$

Medical evidence is thus vital. Bolam states that a doctor is not negligent if there is a 'responsible body' of medical opinion in support of her actions. The body does not have to be large, and indeed the courts have accepted very small numbers in support. ${ }^{87}$ Also worthy of note is the fact that the evidence does not need to come from doctors who have already done what the defendant doctor did. Instead, the supporting doctors need only testify that they might have done the same in the circumstances. This is particularly important in relation to innovative treatments, as it allows Bolam to operate even for treatments that have yet to be tried by anyone. An example of this is the case of Simms v Simms. ${ }^{88}$ The case concerned two patients with probable variant Creutzfeldt-Jakob disease, who lacked capacity to make their own decisions. No effective treatment existed, but a potential treatment never tried in the United Kingdom had been identified that the patients' parents wished to be administered to them. The court was asked to issue a declaration that the treatment would be in their best interests. The case has been used by the Bill team as an example of the unsatisfactory nature of Bolam in assessing genuinely innovative treatment. ${ }^{89}$ In particular, this passage from Simms has been quoted by the Bill team:

The "Bolam test" ought not to be allowed to inhibit medical progress. And it is clear that if one waited for the "Bolam test" to be complied with to its fullest extent, no innovative work such as the use of penicillin or performing heart transplant surgery would ever be attempted. ${ }^{90}$ 
However, what supporters of the Bill do not then acknowledge is that Butler-Sloss LJ held that because there was a body of medical evidence in support of the treatment, and in view of the fact that the alternative was the inevitable death of the patients, the treatment would indeed be in the patients' best interests. Thus,

I am satisfied, consistent with the philosophy that underpins the "Bolam test", that there is a responsible body of relevant professional opinion which supports this innovative treatment. That is, in my view, subject to the seriousness of the risks involved and the degree of benefit that might be achieved. ${ }^{91}$

In this case, then, Bolam was no bar to innovative treatment, either on a practical or philosophical level. In fact, the contrary is true: it was used to justify treatment. This is because the experts are asked to look at the rationale behind the treatment rather than confirm that they had themselves provided it.

The second step in the test for negligence is provided by Bolitho. This allows a court to assess the content of the evidence presented by the defendant's experts and to reject it if it is 'unable to withstand logical analysis'.92 It was made plain by Lord BrowneWilkinson in the House of Lords that this was envisaged as applying only in 'rare case[s] ${ }^{93}$ Nevertheless, Bolitho allows the court to assess not just whether other doctors might have done as the defendant doctor did, but also the content of that decision. It therefore provides a normative element to negligence as it enables a court to establish what ought to have been done. ${ }^{94}$ The court does this by 'weighing the 
relative risks and benefits' involved in the decision to be taken and, if this has been improperly undertaken, intervene to find the decision to constitute a breach of duty notwithstanding the peer support. ${ }^{95}$ This is consistent with Bolam because, as the court in Bolitho noted, the Bolam test does specify that the doctor must conform to a responsible body of medical opinion. ${ }^{96}$ Bolitho also serves to stiffen Bolam. Courts beforehand had too often retreated in the face of the mere existence of medical evidence, confusing involvement with unjustified interference, resulting in what was seen as a surfeit of deference to the medical profession. ${ }^{97}$

To summarise, then, the test for negligence comprises of two parts. First, Bolam invites the doctor to provide peer validation for her decision by demonstrating that there is a body of medical opinion that would support her decision. It is important to remember that the expert witnesses are asked whether they might have acted in the same way as the defendant doctor in the same circumstances, not whether they have already done so. As we have seen from Simms, applying Bolam to a genuinely innovative treatment is unproblematic. In the second part, Bolitho provides the safeguard of allowing the court to reject that body of evidence if it is unable to withstand logical analysis. This is the legal regime that applies to all professionals, from architects to barristers as well as doctors. Finally, it should be remembered that not a single case has so far been produced as an example of a doctor being sued for providing innovative treatment.

\subsection{The MIB Framework}


As noted above, the only perceived inhibitor of innovative treatment identified by the Bill team is the fear of litigation; and it is therefore unsurprising that removing this is therefore the sole aim of the MIB. The theory behind the Bill's framework is to bring the Bolam test forward to before treatment, rather than after it. This has been described by the Bill's drafters as the 'policy intent' of the Bill. ${ }^{98}$ As Lord Saatchi explained to the House of Lords,

the Bill achieves its aim — safe and responsible innovation — in a simple way. It moves the Bolam 'responsible persons' test from after the event to before the event. The result is that doctors are not obliged to speculate in advance about what might happen in a subsequent trial, and they can move forward with confidence, safe in the support of a responsible body of medical persons — in other words, the Bolam test brought forward. This crucial time change removes any uncertainty and ambivalence about what is or is not lawful medical innovation. ${ }^{99}$

Thus, the fear of innovation is removed by settling the question of legal liability before rather than after treatment. As Lord Saatchi notes, by doing this doctors will be reassured as there can be no threat of being sued in negligence if there is an adverse outcome for the patient. Such an approach means that, by definition, a doctor who complies with the safeguards contained within the Bill cannot be found negligent by a court. If this were not the case, then the 'policy intent' of the Bill, as well as the single solution to the single problem that the Bill identifies, are lost. Consequently, it is imperative that the safeguards, contained in s.1(3), are robust. The major ones are considered in turn below. 


\subsubsection{S.1(3)(a) - Obtain the views of one or more appropriately qualified doctors in}

relation to the proposed treatment. Consultation with at least one appropriately qualified colleague forms the fundamental basis of the approach to patient safeguards adopted by the Bill. As noted above, the aim is to give effect to the Bolam peer review process at an earlier stage than is currently required by law. The Bill team has claimed that, because the current law requires no consultation before treatment, the Bill's framework is more robust. ${ }^{100}$ However, if this is the intention then the execution is inadequate, and not just because ultimately Bolam requires a responsible body of peer approval rather than that of 'at least one' colleague. Indeed, of note in this subsection is not what is required but what is not made clear. While, as noted above, s.1(4) defines 'appropriately qualified' as someone having 'appropriate expertise and experience in dealing with patients with the condition in question', the word 'appropriate' is itself not defined. This is obviously nebulous, and will no doubt be the subject of legal challenge should a patient be injured and the doctor seek to rely on the Bill. Also, no mention is made of any requirement that the consultee be independent of the consulter. There is therefore nothing in the Bill to prevent two like-minded doctors, perhaps even partners in their own private practice, consulting each other as a matter of course. Each would essentially indemnify the other. Thus, this paragraph is intended to protect patients by requiring peer validation of a decision, but it entirely fails to do so. Rather, it serves merely to act as protection for the doctor. While this is consistent with the Bill's identification of a fear of litigation as a barrier to innovation, it necessarily removes rights from patients as a consequence. Moreover, the MIB framework certainly requires less than Bolam currently does, and it is equally certainly less effective. 


\subsubsection{S.1(3)(b) - take full account of the views obtained under paragraph (a) (and do}

so in a way in which any responsible doctor would be expected to take account of such views). This paragraph can be divided into two questions: first, what is required by a duty to consult; and, secondly, what is meant by taking account of those views in a way that a reasonable doctor would? Moreover, answering the first of these questions also invites us to consider the potential legal liability of the consultee. So what does a duty to 'consult' actually entail? The claim originally put forward by the Bill team has been that this effectively entails a duty to secure the agreement of the consultee - a line that was adopted on a great many occasions by Lord Saatchi and other members of the Bill team. ${ }^{101}$ Even in the House of Lords, when Lord Turnberg sought to introduce an amendment to the Bill to ensure that agreement was explicitly required, Lord Saatchi responded that it was not needed as agreement was already effectively required by the Bill. ${ }^{102}$ Indeed, even now the Bill's website states that the consulting doctor must achieve a 'consensus' in favour of his proposed innovative treatment. ${ }^{103}$ This was always a tenuous claim. ${ }^{104}$ It rested on advice given by the Bill's lawyer, which provided four cases that purported to demonstrate that a duty to consult was a high hurdle for a doctor to jump over. ${ }^{105}$ Nevertheless, none of the cases state that consensus is required.

The first case cited as an example is the landmark case of Gunning. ${ }^{106}$ This case produced the four principles that must be satisfied for a consultation to be lawful:

To be proper, consultation must be undertaken at a time when proposals are still at a formative stage; it must include sufficient reasons for particular 
proposals to allow those consulted to give intelligent consideration and an intelligent response; adequate time must be given for this purpose; and the product of consultation must be conscientiously taken into account when the ultimate decision is taken. ${ }^{107}$

These principles are well established, and have recently been affirmed by the Supreme Court, which labelled them 'a prescription for fairness'. ${ }^{108}$ Two of the other three cases cited by the Bill team, Coughlan and Compton, merely cite and approve of the Gunning principles. The final case, Aylesbury Mushrooms, relates to the question of who to consult and was decided over a decade before Gunning, and it is difficult to see what it adds, given that s.1(3)(a) of the Bill already requires the consultee to be someone who is appropriately qualified. The most critical of the Gunning criteria for our purposes is the last one: that the product of the consultation must be conscientiously taken into account. This is certainly not an empty requirement, and clearly a consultation executed despite the decision already having effectively been taken will be unlawful. ${ }^{109}$ However, this does not mean that a consultation cannot be entered into with the consulter already having a preferred option in mind. ${ }^{110}$ Thus, "to have an open mind does not mean an empty mind ... provided that his mind is open to the possibility that further information or argument may lead to a different conclusion' ${ }^{111}$

Clearly, this falls far short of a duty to achieve a consensus - it is instead merely a requirement that the views of the consultee are considered with some possibility of the consulter changing her mind on the basis of them. Given this, as demonstrated below, it is entirely possible that a misconceived but stubborn or arrogant doctor 
(exactly the sort who we do not want to be innovating) might satisfy the Gunning criteria by listening to a dissenting consultee's views, thinking about them honestly but still rejecting them and carrying on regardless.

But would this constitute taking views into account in 'a way in which any responsible doctor would be expected' to? There are two ways that one might frame a duty to take the consultee's views into account 'responsibly'. The first relates to process and procedure, and it might simply be argued that so long as the law cited above is followed and the consultation is approached with an open mind, then that is sufficient. After all, as the Bill's drafter has himself argued, a duty to consult does not provide the consultee with a veto. ${ }^{112}$ However, the courts might take advantage of this wording to assess the content of any decision by the consulter to reject the views of the consultee, using Bolam and Bolitho to assess whether such a rejection of the consultees' views by the consulter was reasonable by undertaking a risk/benefit assessment and adducing expert evidence regarding what other doctors would have done. This would certainly help to mitigate the indemnity offered to the most arrogant and reckless of innovators, and the general mood of medical law at the moment would support such an interventionist interpretation. ${ }^{113}$ However, it would also go against the 'policy intent' inherent in the MIB that the question of legal liability is settled before treatment rather than after it. Moreover, this only relates to situations where the consultee objects to the proposed treatment. What about when she agrees?

When that is the case, then the Bill is quite clear: so long as the doctor has complied with the other requirements in s.1(3) (in particular 1(3)(d), which I discuss below), 
then it is not open to a court to find her negligent. It thus becomes important to assess just what standard of consultation is provided for in the Bill. In a briefing note provided by the Bill team's lawyer, Daniel Greenberg, it was finally admitted (despite no significant amendments to s.1(3)) that agreement was not after all required by the MIB, and that this was deliberate. However, this admission also contained a worrying insight into how the Bill team envisages the mechanics of the process of consultation:

There has also been pressure to turn the requirement to consult colleagues into a requirement to obtain colleagues' written consent. These amendments do not give effect to that suggestion. Senior doctors consulted by Lord Saatchi expressed concern about giving formal written consent to another doctor's proposed course of treatment, without knowing the full history and other circumstances, while they would be relaxed about expressing a view of the soundness of the doctor's proposal as described to them. Lawyers consulted were also concerned about a possible new form of legal liability for consenting doctors. The requirement to record views in the patient's notes should introduce the necessary formality, transparency and accountability, while avoiding both of these objections. ${ }^{114}$

It would seem that there has been a concern that, if the treating doctor is indemnified by consultation, then claimants may try to make the consultees liable instead. This is, it must be said, certainly possible. The proposed solution appears to be to informalise the consultation so that no legal liability may accrue to the consultee. This cannot be supported in my view. Indeed, the question of whether a duty of care is owed to a person depends not on whether the consultation is informal, but instead on whether 
there is such a relationship between the parties that the defendant should have regard for the welfare of the claimant. ${ }^{115}$ The doctor-patient relationship has long been accepted as giving rise to such a duty, and if a doctor knows that her opinion will be used to justify the treatment of a specific patient, then there is certainly proximity between the parties. ${ }^{116}$ There is also a danger of foreseeable harm, no immediately apparent reason why it would not be fair, just and reasonable for a duty of care to be imposed. Counsel for the defendant might argue that the consultee was providing an important social good in allowing innovation to flourish, but it is my view that the doctor-patient relationship is so well established as giving rise to a duty of care that a court would struggle to see a distinction between this relationship and any more orthodox one between a patient a doctor. In the event that the courts did not find that they could simply define the consultee's role as giving rise to a traditional doctorpatient relationship, it would certainly be open to them to apply the Caparo principles - proximity, foreseeability of harm and whether the imposition of a duty is fair, just and reasonable as discussed above - anew and to find that a duty of care is, in fact, owed by consultees. ${ }^{117}$

Nevertheless, the informal nature of the consultation with a colleague that is envisioned by the Bill team as a response to this is extremely worrying. The very idea that Bolam (as modified by Bolitho) - which after all requires an in depth and personalised critique of medical decisions and the reasons for them, with experts from both sides examining the specifics of the decisions taken by the doctor - may be superseded by a system where the consultee is unaware of the 'full history and other circumstances' of the patient constitutes a serious weakening of the legal scrutiny of decisions. It is certainly not a like for like replacement. 
Therefore, s.1(3)(b) can be seen to be extremely flawed. If the consultee agrees with the consulter, on the basis of what is envisaged as being little more than a generalised, informal discussion, then the consulter is specifically granted immunity by the Bill. Ironically, the greater danger may be faced by the consultee. If the consultee does not support the consulter, then the situation is less settled, and it may be possible for the courts to become involved although, as I argue below, this would be to go against the entire philosophy behind the Bill. It is certainly not a satisfactory paragraph given its importance.

4.2.3 S.1(3)(d) - consider any opinions or requests expressed by or in relation to the patient, the risks and benefits that are, or can reasonably be expected to be, associated with the proposed treatment, the treatments that fall within the existing range of accepted medical treatments for the condition, and not carrying out any of those treatments, and any other matter that it is necessary for the doctor to consider in order to reach a clinical judgment

This paragraph essentially requires that the doctor interact with the patient and seek her opinion. It is inconceivable that any court would authorise innovative treatment where the patient has said that she does not want it, and indeed s.1(3)(c), states that the patient's consent must be given before the doctor is covered by the MIB. Other than that, s.1(3)(d) merely asks the doctor to consider the risks and benefits of the standard and proposed treatments, as well as inaction. Again, and as I discuss below, there would seem to be no provision for a court to assess the content of this consideration, merely whether it has occurred. 


\subsection{The Inherent Contradiction Within the Bill}

The Bill team has claimed, as mentioned above, that the legislation merely seeks to move Bolam forward to before treatment takes place. However it is clear that what the MIB proposes is significantly less robust in protecting patients than the current Bolam test (thus inlcuding Bolitho), despite protestations to the contrary from the Bill's supporters. ${ }^{118}$ Bolam engages several experts in the field, and constitutes a rigorous, detailed examination of the content of decisions that were made in the specific context of the individual patient. As we have seen above, the consultation imagined by the Bill does not require this. Rather, only a single other doctor need be consulted, and it is even envisioned that it might proceed without the consultee being aware of the individual patient's full history. It essentially constitutes a conversation in principle, which is far less exacting than the Bolam.

Furthermore, the Bill most certainly dispenses with Bolitho. If the question of liability is to be settled before treatment, then it is clear that there is no room for posttreatment review by a court:

if the decision regarding liability must be made before treatment is provided, then by definition it cannot be reviewed afterwards. Thus, the Bill still does not seem to provide a mechanism by which a poor decision (either with or without peer agreement) can be challenged after the fact if a patient is injured. This is the case even if there are, in retrospect, obvious flaws in the thinking 
behind the decision from the outset. If the court can intervene, then the 'policy intent of bringing forward the Bolam test' is necessarily lost. ${ }^{119}$

In other words, the Bill can be seen to rest on two pillars: the 'policy intent' of bringing the question of liability forward to before treatment to remove the fear of litigation from doctors, and the patient safeguards contained in s.1(3). Unfortunately, they do not and cannot sit comfortably together. Indeed, they are mutually exclusive. The patient protections in s.1(3), which do contain normative words such as 'reasonable' (s.1(1)(d)) and 'responsible' (s.1(1)(b)), would undermine to the point of destruction the notion of removing the fear of litigation from doctors if they allowed the courts to retrospectively assess the content of decisions to innovate. To be clear: if the question of liability is set with certainty before treatment, then any patient safety clauses are redundant, as the courts would only be able to check whether the process was followed, and not the content of the decision. On the other hand, if the courts can examine the content of decisions under the Bill (thus prioritising patient safety), then it is impossible to settle the question of liability before treatment and thus remove the fear of litigation.

However, the Bill team has both claimed that liability can be settled with certainty before treatment, ${ }^{120}$ and that it will be open to the courts to assess the content of decisions afterwards. ${ }^{121}$ This is clearly impossible and means that the Bill cannot function, even on its own terms. ${ }^{122}$ Given this, at best the MIB will only create uncertainty and lead to more, rather than less, litigation. ${ }^{123}$ This would, of course, go completely against the specific ethos of the Bill and its entire raison d'etre. Alternatively, if the courts follow the legislative intent of the Bill and do not allow 
themselves to assess the content of decisions, then the Bill would become an active danger to patients and a serious weakening of the law. This can be seen by reference to three examples.

Our first example relates to good, responsible medical practice. Let us take a situation that the Bill claims to be designed to address. The Bill's website uses Ebola as an example of a condition where the Bill would be of use, and quotes Prof Peter Smith as saying that:

If I had a cancer that say had a $70 \%$ mortality in six months and there was an experimental therapy and there's no data on it, but which might actually improve that survival - and it looked as if it wasn't going to kill me tomorrow - then I might well want the opportunity of taking that drug or whatever it was. And that's the situation the Ebola patients are in.

I think the situation here [with Ebola] was sufficiently dire that there was encouragement to actually shortcut the normal processes. I mean, to use therapies for which there may not be as strong an evidence base with respect to safety as you would normally require - but these were special circumstances. $^{124}$

Under current law, if an experimental procedure that had not been licenced for Ebola was available, as was in fact the case, then there is nothing to stop it being used. This can be seen by the fact that the patient in question was actually treated. ${ }^{125}$ The same can be said of the case of VCJD in Simms, as discussed above. The Bill was therefore 
not needed for this to be possible, and the current law would not prevent treatment. Even if the current law were an impediment, given that the Bill does not allow doctors to do anything that they cannot already do, it would not have authorised treatment that could not already be authorised. Therefore, in this case the Bill is not needed and, if it were, it would not have been able to help.

But what if the patient were injured and decided to sue in negligence? According to the Bill, so long as the procedure in the Bill were followed the doctor would not be negligent. However, it is also inconceivable that such a doctor would be liable in negligence under the current law. If there was no standard treatment, or it was ineffective, and the experimental treatment was the only hope, then the case would be very similar to Simms. It is virtually impossible that, in such a situation, the balance of risks and potential benefits (as required by Bolitho) would lead a court to any other decision than that the treatment was justified, so long as some other doctors were supportive of the overall approach. Put simply: if there is nothing to be gained by using the standard treatment, the experimental treatment had a chance of improving the patient's condition and the patient consents to taking the risk, then the risk/benefit analysis can only result in a conclusion that the decision to innovate was reasonable. Moreover, given that in the case of Ebola the experimental treatment had been considered by the World Health Organisation, the 'withstanding logical analysis' criterion is easily satisfied. ${ }^{126}$

The case of Ebola, then, is not a good advert for the Bill - not only would the MIB not enable any treatment that could not be provided without it, but it would provide no additional protection to the responsible doctor than is already provided by the law. 
Moreover, the current law in this area already provides the responsible clinician with all the protection that she needs, suggesting that the Bill would be superfluous.

Our second example relates to an overconfident doctor. A useful set of facts would be facts similar to those in the case of Clark $\mathrm{v}$ Maclennan, a decision criticised by Lord Saatchi in the past. ${ }^{127}$ In Clark, a doctor operated to relieve the patient's stress incontinence one month after she gave birth. The standard practice was to wait for three months, because of the risk of haemorrhage and also because waiting was seen as more likely to produce successful healing. The defendant could find no other doctors who said that they might have done as he did and not wait. This would be seen as 'innovation' under the Bill, as it is a departure 'from the existing range of medical treatments' for the condition. ${ }^{128}$ Let us pretend for a moment that the Bill had been passed at that point, and that the doctor was seeking to rely on it. Let us also pretend that the doctor was honest but misguided. She had consulted colleagues who had advised her to wait another two months, but while she had carefully and genuinely considered their guidance, she nevertheless felt that the early surgery would be successful. She had also convinced the patient that she could successfully perform the surgery early, and considered the risks and benefits of both the early surgery and waiting, but again concluded that the early surgery would work. In other words, this doctor would have complied with the process under s.1(3) of the MIB.

In Clark itself, the operation was unsuccessful, the patient haemorrhaged and was left with permanent stress incontinence. In other words, she suffered precisely the harm that waiting for three months was supposed to prevent. The court found that, given the lack of peer support for the early surgery and the nature of the risk, it was not 
reasonable to perform the procedure four weeks after giving birth. However, the MIB would face a quandary. In theory, the doctor has satisfied the requirements of the process in s.1(3). It is the content of her decision that is faulty rather than the process involved in the making of it. If the court followed the Bill then a patently poor decision, that does not have the support of other doctors and had caused an avoidable and permanent injury to the patient, would nevertheless not be classed as negligent. However, if the court decided that it could assess the content of the decision, then the notion of 'bringing Bolam forward' and removing the fear of litigation by providing certainty before treatment would be completely lost.

But if the Bill were to have any effect at all, the doctor would have to be indemnified. There is absolutely no point to it otherwise. This example also demonstrates that, contrary to the claims recounted above, the Bill is not more exacting than Bolam. Indeed the contrary is true as a misguided doctor, however well intentioned, can rely on the Bill without achieving any consensus at all.

The final example relates to 'quacks'. ${ }^{129}$ Many opponents of the Bill argue that the Bill will provide protection to quacks and charlatans. ${ }^{130}$ With cancer in particular there are many bodies that claim to provide alternatives to conventional therapies such as chemotherapy, and many of these have been criticised as irresponsible by the medical community. ${ }^{131}$ An example can be found in a recent case from Australia, which concerned a doctor who was found by the court to have involved herself in alternative treatments for cancer patients that were harmful to them. ${ }^{132}$ Of the seven who were subjected to the 'treatment', four died within the first two weeks, another died six weeks after 'treatment' commenced, and another after 9 weeks. The seventh 
patient stopped the treatment after 11 days, and survived a further four and a half years. ${ }^{133}$ Such practitioners may either convince the patient to forego regular therapies or provide treatments that, in some cases, may actively harm the patient. Again, any treatment would be 'innovative' under the Bill, and therefore potentially receive protection. In the case of charlatans, the danger is that like minded doctors might act as consultees under reciprocal arrangements, thus indemnifying each other by agreeing with the consulter's proposed course of action. So long as they believe in what they are doing, they can honestly 'consider' the relative risks and benefits in relation to their treatment and the standard options. Again, s.1(3) would be satisfied in such a scenario, and if the intent of the Bill were followed the court would not be able to review the content of the decisions made by the doctors. Moreover, if the Bill team's briefing note is accurate - and as argued above I am not convinced that it is then the patient would not even be able to seek redress from the consultee as an alternative. In this case, the current law contains the tools necessary for the courts to provide compensation, but the MIB would remove them and indemnify what is actively harmful treatment on vulnerable patients.

What can be seen from these examples is the serious nature of the adverse, unintended consequences that the Bill would make possible. Misguided doctors would be protected, as would quacks and charlatans. Meanwhile, 'good' doctors providing important innovative treatment would not gain any advantage at all, as they are already protected by the law. These examples, and the discussion of the framework provided by the Bill, also highlight the fact that the Bill seriously weakens patient protection and certainly offer patients far less than Bolam and Bolitho currently do. The tragedy is that this weakening of safeguards is proposed in order to solve a 
problem that does not exist. Put in the terms of a cost/benefit analysis, the Bill confers no benefits to those who deserve it, while carrying significant risks. It should not be passed.

\section{Conclusion}

The MIB is markedly different in form to the way that it has been presented. It is not legislation specifically targeted at rare cancers and incurable diseases that enjoys popular support and removes the largest impediments to doctors innovating responsibly. In fact, it is the opposite: a Bill that applies to all conditions (except cosmetic surgery), which is opposed by virtually all key stakeholders and tries to solve a problem for which its supporters cannot provide any evidence. It is inevitable that there will be doctors who fear litigation - ironically, there will probably be more of them following the Bill's passage through parliament. Yet the answer surely lies in education rather than a change in legislation if the fears are misplaced. The GMC already requires medical law and ethics to comprise a part of the core curriculum for medical schools, and if a fear of litigation is indeed a problem then this might be one avenue for disabusing them of any misapprehensions. Yet we do not even know whether this fear is prevalent on a large scale, as no evidence has been provided. If the law is no impediment to innovation then this legislation is not needed.

This is particularly the case given that it significantly weakens the patient safeguards currently offered by Bolam and Bolitho. Moreover, Simms demonstrates the ease with which Bolam can adapt to innovative treatment. As I have demonstrated, the Bill's proposed framework does nothing to help responsible doctors, while facilitating and 
indemnifying overconfident doctors and quacks. It makes no distinction between senior specialists (who we would want to encourage to innovate) and the most junior generalist (who we would wish to be supervised more closely). In other words, this is not just an unnecessary but benign Bill; it may be genuinely harmful to patients. This is all in order to solve a problem that does not exist. Even worse, the Bill in internally inconsistent, with its two pillars (removing the fear of litigation and protection for patients) being mutually exclusive. If the Bill were to pass, it may well even lead to an increase in litigation while the courts tried to navigate its way through the mess. Even then, the Bill would not address the real barriers to innovation, identified by the Association of Medical Research Charities as being issues such as regulatory complexity and funding. ${ }^{134}$ It is worth remembering that the Bill does not allow doctors to do anything that they cannot currently do, does not provide any funding to facilitate access to and use of drugs that can currently be used, and promises a register that is practically and ethically dubious and is in any event, as mentioned above, 'a chimera'. 135

Put bluntly, it is extraordinary that this Bill has made it as far as it has. It is essential that parliament rectifies its error at the very next possible opportunity.

Acknowledgments: I am grateful to Darren Conway, Sara Fovargue, Sofia Hart and David Hills for looking at previous drafts of this paper, and to the anonymous reviewers. Their input has been invaluable. 
${ }^{1}$ Hansard, 27 June 2014, Col 1450-1451. See also M. Saatchi, 'We Must Liberate Doctors to Innovate', Daily Telegraph, 26 January 2014.

${ }^{2}$ Ibid. See also the first guide to the Bill produced by the Bill team: 'How Can an Act of Parliament Cure Cancer? A Guide to the Medical Innovation Bill' (https://suturedgrape.files.wordpress.com/2014/10/mibguide.pdf, last accessed $4^{\text {th }}$ ), which states on p11 that the law 'defined medical negligence as deviation from standard practice'.

${ }^{3}$ Ibid.

${ }^{4}$ The MIB's website contains details of the team and reveals that they are funded personally by Lord Saatchi: http://medicalinnovationbill.co.uk/who-are-the-medical-innovation-bill-team/ (last accessed $4^{\text {th }}$ July 2015).

${ }^{5}$ https://medicalinnovationbill.co.uk, last accessed 4th July 2015.

${ }^{6}$ https://twitter.com/saatchibill, last accessed 4th July 2015.

${ }^{7}$ https://www.facebook.com/SaatchiBill, last accessed 4th July 2015.

${ }^{8}$ http://saatchibill.tumblr.com, last accessed 4th July 2015.

${ }^{9}$ This was revealed in a briefing note to the House of Lords (see MIB, 'Medical Innovation Bill, Session 2014-5 Briefing Note', $10^{\text {th }}$ June 2014 (http://medicalinnovationbill.co.uk/wpcontent/uploads/2014/05/Medical-Innovation-Bill-Briefing-Note-10th-June-2014.pdf, last accessed $4^{\text {th }}$ July 2015), p10.

${ }^{10}$ See http://www.telegraph.co.uk/news/health/saatchi-bill/ (last accessed $4^{\text {th }}$ July 2015).

${ }^{11}$ A good summary of opposition to the Bill was provided by the Welsh Assembly: see National Assembly of Wales Health and Social Care Committee, Report on Legislative Consent Memorandum for the Medical Innovation Bill, $29^{\text {th }}$ January 2015, paras 17-20. See also D. Hills, 'Bad Consultation, Bad Bill' (https://wanderingteacake.wordpress.com/the-saatchi-bill-2/bad-consultation-bad-bill/, last accessed $4^{\text {th }}$ July 2015). 
${ }^{12}$ http://www.stopthesaatchibill.co.uk,

${ }^{13}$ D. Nutt, 'Saatchi Bill Will Stifle Explosion of NHS Litigation' (2015) 139(1) Solicitors Journal (http://www.solicitorsjournal.com/comment/saatchi-bill-will-stifle-explosion-nhs-litigation, last accessed $4^{\text {th }}$ July 2015).

${ }^{14}$ MIB, 'Nick Clegg and the Lib Dems Refuse to Debate the Bill - And Kill It', 28 February 2015 (http://medicalinnovationbill.co.uk/nick-clegg-lib-dems-refuse-debate-bill-kill/, last accessed $4^{\text {th }}$ July 2015).

${ }^{15}$ http://services.parliament.uk/bills/2015-16/medicalinnovation.html, last accessed $4^{\text {th }}$ July 2015.

${ }^{16}$ Indeed, the Bill team claims that it enjoys and employs a 'one team' philosophy with the government (see, for example, MIB, 'Did the Medical Innovation Bill Team Work with the Department of Health on One Consultation - Or Were There Two, As Some Opponents Claim?', 26 January 2015

(http://medicalinnovationbill.co.uk/did-the-medical-innovation-bill-team-work-with-the-department-ofhealth-on-one-consultation-or-were-there-two-as-some-opponents-claim/, last accessed $4^{\text {th }}$ July 2015).

${ }^{17}$ MIB, 'The Bill is Introduced Into the House of Commons', 24 June, 2015

(http://medicalinnovationbill.co.uk/the-bill-is-introduced-into-the-house-of-commons/, last accessed $4^{\text {th }}$ July 2015).

${ }^{18}$ MIB s.1(1).

${ }^{19} \mathrm{Ibid}$, s.1(2).

${ }^{20} \mathrm{Ibid}, \mathrm{s.1}(4)$.

${ }^{21}$ I consider this in more detail below in section 4.3 of this paper.

${ }^{22}$ http://medicalinnovationbill.co.uk/but-wont-the-bill-deny-patients-who-have-been-harmed-the-rightto-sue-and-get-compensation/, last accessed $4^{\text {th }}$ July 2015.

${ }^{23}$ MIB Guidance Notes on Amendments ( ${ }^{\text {th }}$ Sept 2014), para 9 (available at http://medicalinnovationbill.co.uk/wp-content/uploads/2014/09/Guidance-note-MIB.pdf, last accessed $29^{\text {th }}$ April 2015).

24 'How Can An Act of Parliament Cure Cancer?', above n2.

${ }^{25}$ See, for example B. Riley-Smith, 'Saatchi Bill to Save Patients From "Horror and Indignity" of Outdated Treatments to Pass Lords on Friday', Daily Telegraph, 23 $3^{\text {rd }}$ January 2015 (http://www.telegraph.co.uk/news/health/news/11364374/Saatchi-bill-to-save-patients-from-horrorand-indignity-of-outdated-treatments.html, last accessed $4^{\text {th }}$ July 2015). 
${ }^{26}$ Department of Health, Report on the Consultation on the MIB (Department of Health, 2014), para 81.

${ }^{27}$ Above n2. See also M. Saatchi, 'How Can an Act of Parliament Cure Cancer?' (2013) 106 J Roy Soc Med 169.

${ }^{28}$ Above n 2, p7.

${ }^{29}$ MIB s.1(7).

${ }^{30}$ See http://medicalinnovationbill.co.uk/about-the-medical-innovation-bill/ (last accessed $1^{\text {st }}$ May 2015).

${ }^{31}$ Ibid.

32 'Doctors too Scared of Getting Sued to Find Cure for Cancer, Says Lord Saatchi', Daily Telegraph, 2 December 2012.

${ }^{33}$ See the latest Guide to the MIB, February 2015 (http://medicalinnovationbill.co.uk/wpcontent/uploads/2015/01/Guide-to-the-Medical-Innovation-Bill.pdf, last accessed $1^{\text {st }}$ May 2015), 10.

${ }^{34}$ Department of Health, Legislation to Encourage Medical Innovation: A Consultation (Department of Health, 2014), p4.

${ }^{35} \mathrm{Ibid}, 4-5$.

${ }^{36} \mathrm{~A}$ list of those who agreed and disagreed with the proposition can be found in Report on the Consultation on the MIB, paras 8-18.

${ }^{37}$ The response can be found at: http://scienceblog.cancerresearchuk.org/wpcontent/uploads/2014/05/Cancer-Research-UK-consultation-response-draft-Medical-InnovationBill.pdf, last accessed $6^{\text {th }}$ June 2014, p2.

${ }^{38}$ MNDA, Response to the Consultation on the MIB, http://www.mndcampaigns.org/assets/0003/0040/Medical_Innovation_Bill_consultation response by the MND_Association.pdf, last accessed $6^{\text {th }}$ June 2014, p2.

${ }^{39}$ AMRC, Re: Legislation to Encourage Medical Innovation: A Consultation, http://www.amrc.org.uk/sites/default/files/doc_lib/2014_AMRC_to\%20Department_of_Health_consult ation_on_Legislation to encourage _medical_innovation.pdf, last accessed $6^{\text {th }}$ June 2014, para 2; BMA, 'Legislation to Encourage Innovation - A Consultation. BMA Response', p1. The document can be downloaded from: http://www.stopthesaatchibill.co.uk/what-do-doctors-lawyers-and-medical-charities-

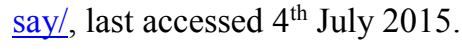


${ }^{40}$ MDU, 'MDU Response To: Legislation to Encourage Innovation', p5. The document can be downloaded from: http://www.stopthesaatchibill.co.uk/what-do-doctors-lawyers-and-medical-charitiessay/, last accessed $4^{\text {th }}$ July 2015.

${ }^{41}$ MPS, 'MPS Response To: Legislation to Encourage Innovation', p1. The document can be downloaded from: http://www.stopthesaatchibill.co.uk/what-do-doctors-lawyers-and-medical-charities-

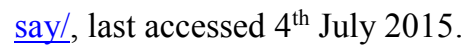

${ }^{42}$ NHSLA, 'Response to Legislation to Encourage Innovation - A Consultation'

(http://www.stopthesaatchibill.co.uk/wp-content/uploads/2014/06/NHS-Litagation-Authority.pdf, last accessed $4^{\text {th }}$ July 2015), p1.

${ }^{43}$ For more see http://www.stopthesaatchibill.co.uk/what-do-doctors-lawyers-and-medical-charitiessay/

${ }^{44} \mathrm{DoH}$, Report on the Consultation on the MIB: Summary of Responses and Next Steps (https://www.gov.uk/government/uploads/system/uploads/attachment_data/file/338274/medinnbill_res ponse.pdf, last accessed $4^{\text {th }}$ July 2015), para 8.

${ }^{45}$ Lord Woolf, 'Saatchi Bill: Your Last Chance to Help', Daily Telegraph, 24 ${ }^{\text {th }}$ April 2014.

${ }^{46}$ J. van der Luit-Drummond, 'Former Lord Chief Justice Unable to Substantiate Argument for MIB'

Solicitors Journal, $11^{\text {th }}$ December 2014. (http://www.solicitorsjournal.com/news/personalinjury/medical-negligence/former-lord-chief-justice-unable-substantiate-argument-medic, last accessed $3^{\text {rd }}$ May 2015). Barton is co-author of M. Powers and A. Barton, Clinical Negligence ( $5^{\text {th }}$ Edition, London: Bloomsbury, 2015).

${ }^{47}$ Ibid.

${ }^{48}$ C. Campbell-Holt (Ed), Lord Woolf: The Pursuit of Justice (Oxford: Oxford University Press, 2008). See HL Debate, Col 2030-2031, 12 December 2014.

${ }^{49}$ The most likely chapters are 20 and 21. See also J. van der Luit-Drummond, 'Huzzah! Lord Woolf has written a Book But Still Dodges the Question', Solicitors Journal, 17 $7^{\text {th }}$ December 2014 and, in relation to the refusal to elaborate, J. van der Luit-Drummond, 'Lord Woolf Unrepentant Over Failure to Substantiate Support for Saatchi Bill', Solicitors Journal, $5^{\text {th }}$ January 2015.

${ }^{50}$ Ibid.

${ }^{51}$ The claim had, however, also been made before the consultation - with Lord Saatchi noting the 'overwhelming tide of support ... from doctors, lawyers and, most of all, from those whose wives, 
husbands, sons, daughters, brothers and sisters have died wasted deaths from cancer' (M. Saatchi, 'We Must Liberate Doctors to Innovate', above n1).

${ }^{52}$ See, for example, M. Saatchi, 'Saatchi Bill: People Power Drives the Fight to Cure Cancer', Daily

Telegraph, 1 May 2014 (less than a week after the consultation closed). See also D. Nutt, 'Saatchi Bill: Doctors Should Embrace Innovation, Not Fear It', Daily Telegraph, 2 June 2014, although note that Nutt refers to a 'minority - but a significant one' that voiced opposition.

${ }^{53}$ See D. Hills, 'Bad Consultation, Bad Bill', above n11. The Bill team issued a rebuttal (MIB, 'Did the MIB Team Work With the Department of Health on One Consultation - Or Were There Two, As Some Opponents Claim?' above n16. Hills then issued a further response: D. Hills, 'Under the Bus', $3^{\text {rd }}$ February 2015, https://wanderingteacake.wordpress.com/the-saatchi-bill-2/under-the-bus/, last accessed $5^{\text {th }}$ May 2015.

${ }^{54}$ MIB Session 2014-15 Briefing Note, $10^{\text {th }}$ June 2014, at 11. See also Hills, 'Bad Consultation, Bad Bill', above n11.

${ }^{55}$ See D. Hills, 'Under the Bus’, above n53 who provides numerous examples.

${ }^{56}$ Above n16.

${ }^{57}$ See, for examples of the claim, S. Knapton, 'Huge Response to Lord Saatchi's MIB', Daily

Telegraph, 1 June 2014; M. Saatchi, 'People Power Drives the Fight to Cure Cancer', above n52, where Lord Saatchi refers to the consultation as 'one of the largest public consultations ever undertaken in this country'.

${ }^{58}$ Knapton, 'Huge Response to Lord Saatchi's MIB', above n57.

${ }^{59}$ M. Saatchi, 'People Power Drives the Fight to Cure Cancer', above n52.

${ }^{60}$ MIB, 'A New Draft of the MIB is Published (Saatchi Bill)', $1^{\text {st June 2014, }}$ http://medicalinnovationbill.co.uk/a-new-draft-bill-is-published/, last accessed $6^{\text {th }}$ May 2015.

${ }^{61}$ See http://services.parliament.uk/bills/2014-15/medicalinnovation/stages.html, last accessed $6^{\text {th }}$ May 2015.

${ }^{62}$ D. Nutt, 'Saatchi Bill: Doctors Should Embrace Innovation, Not Fear It', above n52. Emphasis added. The same claim was made in the briefing note MIB Session 2014-15 Briefing Note, above n9, p11. ${ }^{63} \mathrm{GMC}$, General Medical Council Response to Proposed Bill to Encourage Medical Innovation, at $\underline{\text { http://www.gmc- }}$

uk.org/GMC response to proposed_legislation_to_encourage_medical_innovation_April_2014.pdf 
56053559.pdf, last accessed $6^{\text {th }}$ June, para 6; BMA, Legislation to Encourage Medical Innovation - A

Consultation: BMA Response, the document can be downloaded from http://cloudpage.co/medicalinnovation-bill, p1.

${ }^{64}$ The responses of all of these bodies, and more, can be downloaded from

http://www.stopthesaatchibill.co.uk/what-do-doctors-lawyers-and-medical-charities-say/, last accessed $6^{\text {th }}$ June 2014.

${ }^{65}$ The MDU's response can be found at:

http://www.themdu.com/ /media/Files/MDU/Publications/Consultation\%20responses/MDU\%20respo nse \%20to\%20consultation\%20on\%20Medical\%20Innovation\%20Bill.pdf, last accessed $6^{\text {th }}$ June 2014. For the MPS response see MPS, MPS's Response to Legislation to Encourage Medical Innovation: A Consultation, at http://www.medicalprotection.org/Default.aspx?DN=542f0be1-f73c-4e4c-a480$\underline{\mathrm{d} 694 \mathrm{e} 4 \mathrm{e} 25 \mathrm{c} 81}$, last accessed $6^{\text {th }}$ June 2014.

${ }^{66}$ See Hills, 'Bad Consultation, Bad Bill', above n11.

${ }^{67}$ The most recent voicing of opposition came in June 2015, in the form of a letter to the Independent newspaper from the BMA and Royal Colleges, reaffirming their opposition: 'Medical Innovation Bill Needs Full Scrutiny', The Independent, $18^{\text {th }}$ June 2015.

${ }^{68}$ See, for example, BMA, 'Parliamentary Briefing - Medical Innovation Bill' $24^{\text {th }}$ October 2014 (https://suturedgrape.files.wordpress.com/2014/11/po-briefingmedical-innovationbill-23-10-2014.pdf, last accessed $4^{\text {th }}$ July 2015).

${ }^{69}$ MDU, 'Medical Innovation Will Continue Without Legislation, MDU Says', $6^{\text {th }}$ March 2015 (http://www.themdu.com/press-centre/press-releases/medical-innovation-will-continue-withoutlegislation-mdu-says, last accessed $4^{\text {th }}$ July 2015). P. Bradshaw, 'Innovation Doesn't Need a New Law' BMJ Blogs, $15^{\text {th }}$ March 2015 (http://blogs.bmj.com/bmj/2015/03/17/pallavi-bradshaw-innovationdoesnt-need-a-new-law/, last accessed $4^{\text {th }}$ July 2015).

${ }^{70}$ K. Law, 'Don't Rush Saatchi Drugs Laws', The Times, $23^{\text {rd }}$ February 2015.

${ }^{71}$ Many of the medical research bodies issued a joint briefing voicing opposition to the Bill in March 2015: see, AoMRC, 'Briefing on the Medical Innovation Bill', $6^{\text {th }}$ March 2015 (http://www.wellcome.ac.uk/stellent/groups/corporatesite/@policy_communications/documents/web_d ocument/wtp058818.pdf, last accessed $4^{\text {th }}$ July 2015). 
${ }^{72}$ http://www.mndcampaigns.org/assets/0003/0040/Medical_Innovation_Bill__-

consultation_response _by the _MND_Association.pdf, last accessed $30^{\text {th }}$ June 2015.

73 'Medical Innovation Register', http://medicalinnovationbill.co.uk/medical-innovation-register/, last accessed $7^{\text {th }}$ May 2015. Emphasis added.

${ }^{74}$ Ibid.

${ }^{75}$ This is the view of, for example, the Association of Medical Research Charities, above n71.

${ }^{76}$ HL Debate, Hansard Col 1453, 27 June 2014.

${ }^{77}$ Ibid.

78 'Medical Innovation Register', above n73.

${ }^{79}$ N. Poole, 'The Medical Innovation Register', http://nigelpooleqc.blogspot.co.uk/2015/01/themedical-innovation-register.html, last accessed $7^{\text {th }}$ May 2015.

${ }^{80}$ Ibid. Emphasis added.

${ }^{81}$ Ibid.

${ }^{82}$ There was also a letter printed in The Times signed by 100 senior oncologists voicing this view (K. Lay, 'Saatchi Cancer Drug Bill Could Be Harmful, 100 Experts Warn', The Times, $13^{\text {th }}$ November 2014. This drew a furious response from Lord Saatchi, who wrote a response in the Guardian accusing them of demonstrating complacent and self-satisfied attitudes (M. Saatchi, 'Cancer Patients are Dying Because of Our Downton Abbey Treatment System', The Guardian, 14 ${ }^{\text {th }}$ November 2014.

${ }^{83}$ Health Committee, Oral Evidence: Accountability Hearing with the General Medical Council (HC $846,5^{\text {th }}$ January 2015), para 67 . See also para 66.

${ }^{84}$ M. Saatchi, 'We Now Have Hope of Finding New Ways to Treat Incurable Diseases', Daily Telegraph $24^{\text {th }}$ January 2015.

${ }^{85}$ Bolam v Friern Hospital Management Committee [1957] 1 WLR 583; Bolitho v City and Hackney Health Authority [1998] AC 232. For a fuller explanation see E. Jackson, Medical Law: Text, Cases and Materials ( $3^{\text {rd }}$ Edition, Oxford: Oxford University Press, 2013), chapter 3.

${ }^{86}$ Bolam, above n85, p587.

${ }^{87}$ See, for example, De Freitas v O'Brien [1995] EWCA Civ 28, where 11 of 1000 surgeons was considered a sufficient 'body'.

${ }^{88}$ Simms v Simms [2002] EWHC 2734 (Fam). 
${ }^{89}$ See, for example, M. Rawlins, 'The Saatchi Bill Will Encourage Responsible Innovation in Treatment' (2014) 348 BMJ 2771, enthusiastically reproduced on the MIB's Tumblr page (MIB, 'The “Saatchi Bill” Will Encourage Responsible Innovation in Treatment, Says Michael D Rawlins, President, Royal Society of Medicine', $17^{\text {th }}$ April 2014 (http://saatchibill.tumblr.com, last accessed $4^{\text {th }}$ July 2015). Moreover, the claim is made in both the original briefing paper froduced by the Bill Team (above n2, pp22-3), and the briefing note produced after the DoH consultation closed (above n16, p40). See also Anon, 'Saatchi Soundbites', 27 $7^{\text {th }}$ May 2014, http://dissentingdoc.com/2014/05/27/saatchisoundbites/, last accessed $4^{\text {th }}$ July 2015.

${ }^{90}$ Simms, above n88, para 48.

${ }^{91}$ Ibid, para 51. Emphasis added.

${ }^{92}$ Bolitho, n85, p241-2

${ }^{93}$ Ibid.

${ }^{94}$ For a good description of this point, albeit before Bolitho, see K. Norrie, 'Common Practice and the Standard of Care in Medical Negligence' (1985) Juridical Review 145. See also the classic exposition of this point in J. L. Montrose, 'Is Negligence an Ethical or Sociological Concept?' (1958) 21(3)

Modern Law Review 259.

${ }^{95}$ Bolitho, n85, p241. The court cited Hucks v Cole [1993] 4 Med LR 393 as an example of this being done.

${ }^{96}$ Ibid.

${ }^{97}$ See H. Teff, Reasonable Care (Oxford, Clarendon Press, 1994). See also M. Brazier and J. Miola, 'Bye Bye Bolam: A Medical Litigation Revolution?' (2000) 8(1) Medical Law Review 85 and Lord Woolf, 'Are the Courts Excessively Deferential to the Medical Profession?' (2001) 9(1) Medical Law Review 1.

${ }^{98}$ MIB, Guidance Notes on Amendments, September 2014, http://medicalinnovationbill.co.uk/wpcontent/uploads/2014/09/Guidance-note-MIB.pdf (last accessed 14th May 2015), para 9. See also D. Nutt, 'Saatchi Bill: Doctors Should Embrace Innovation, Not Fear It', above n52.

${ }^{99}$ Hansard, 27 ${ }^{\text {th }}$ June 2014, Cols 1451-1452. Emphasis added.

${ }^{100}$ Indeed, the claim has been made by the Bill team on the Bill website. See MIB, 'Why the Medical Innovation Bill Will Be Safer for Patients', 24 ${ }^{\text {th }}$ November 2014, 
http://medicalinnovationbill.co.uk/why-the-medical-innovation-bill-will-be-safer-for-patients/, last accessed $4^{\text {th }}$ July 2015.

${ }^{101}$ For examples see D. Hills, 'Why the Saatchi Bill Cannot Work' at https://wanderingteacake.wordpress.com/the-saatchi-bill-2/why-the-saatchi-bill-cannot-work/ (last accessed $30^{\text {th }}$ May 2015) and N. Poole, 'Watering Down Patient Protection' at http://nigelpooleqc.blogspot.co.uk/2014/12/watering-down-patient-protection.html (last accessed 30th May 2015).

${ }^{102}$ See J. Miola, 'What the Lords Missed' at http://www.stopthesaatchibill.co.uk/what-the-lords$\underline{\operatorname{missed} /(\text { last accessed 30 }}$ th May 2015).

${ }^{103}$ MIB, 'About the MIB', point 6 on graphic (http://medicalinnovationbill.co.uk/about-the-medicalinnovation-bill/, last accessed $4^{\text {th }}$ July 2015).

${ }^{104}$ J. Miola, 'What the Lords Missed', above n102.

${ }^{105} R \mathrm{v}$ Brent London Borough Council, ex parte Gunning (1985) 84 LGR 168; $R$ v North and East Devon Health Authority, ex parte Coughlan [2001] QB 213, [108]; R (on the application of Compton) v Wiltshire Primary Care Trust [2009] EWHC 1824 (Admin) at para.104; Agricultural, Horticultural and Forestry Industry Training Board v Aylesbury Mushrooms [1972] 1 W.L.R. 190. See http://medicalinnovationbill.co.uk/is-consultation-enough-2/

${ }^{106}$ Ibid.

${ }^{107}$ Coughlan, above n105, summarising the Gunning principles.

${ }^{108} R$ (on the application of Moseley (in substitution of Stirling Deceased)) v London Borough of Haringey [2014] UKSC 56, at para 25, citing R (Royal Brompton and Harefield NHS Foundation Trust) v Joint Committee of Primary Care Trusts [2012] EWCA Civ 472.

${ }^{109}$ See, for example, $R$ (Partingdale Lane Residents Association) v Barnet London Borough Council [2003] EWHC 947 (Admin). See also MIB, 'Is “Consultation” Enough', 1 'st July 2014, http://medicalinnovationbill.co.uk/is-consultation-enough-2/, last accessed $4^{\text {th }}$ July 2015.

${ }^{110}$ Sardar \& Others v Watford Borough Council [2006] EWHC 1590 (Admin)

${ }^{111}$ Royal Brompton and Harefield NHS Foundation Trust $\mathrm{v}$ Joint Committee of Primary Care Trusts [2011] EWHC 2986 (Admin), at paras 16-17.

112 The Bill Team's lawyer, Daniel Greenberg, wrote a 'general note' on consultation which states that a duty to consult 'falls far short of a duty to comply with the consultees' wishes'; see 
http://medicalinnovationbill.co.uk/wp-content/uploads/2014/07/Consultation-Westlaw-Annotated-

Statutes-General-Note-March-by-Daniel-Greenberg20141-copy.pdf, last accessed $4^{\text {th }}$ July 2015.

${ }^{113}$ See, for example, the recent Supreme Court decision in Montgomery v Lanarkshire Health Board [2015] UKSC 11.

${ }^{114} \mathrm{http} / / /$ medicalinnovationbill.co.uk/amendments-to-be-moved-on-report/ (last accessed $30^{\text {th }}$ May

2015). Emphasis added.

${ }^{115}$ The principle is well established, and the doctor certainly does not have to see the patient to owe a

duty. See, for example, Barnett v Chelsea and Kensington Hospital Management Committee [1968] 2 WLR 922.

${ }^{116}$ This is particularly the case when there is a single person (the patient) or group that is easily identifiable. See White v Jones [1995] UKHL 5, where a solicitor was held to owe a duty to the beneficiaries of a will that he had dealt with negligently, because they were an easily ascertainable person or class of persons.

117 Caparo v Dickman [1990] 2 AC 605.

${ }^{118}$ See, for example, an article in the Solicitors Journal by the Dominic Nutt, a member of the Bill team: D. Nutt, 'Saatchi Bill Will Stifle Explosion in NHS Litigation', above n13. Nutt argued that the Bill 'requires the same [as Bolam], but in advance and with greater clarity'.

119 J. Miola, 'The New Amendments - The Bill That Eats Itself', http://www.stopthesaatchibill.co.uk/the-new-amendments-the-bill-that-eats-itself/ (last accessed $4^{\text {th }}$ June 2015).

${ }^{120}$ Examples are provided in D. Hills, 'Why the Saatchi Bill Cannot Work', http://www.stopthesaatchibill.co.uk/why-the-saatchi-bill-cannot-work/, last accessed $4^{\text {th }}$ July 2015. ${ }^{121}$ Indeed, Earl Howe gave Lord Pannick specific assurances on this point in the House of Lords - see J. Miola, 'What the Lords Missed', above n102. For other examples see D. Hills, 'There's Negligence and There's Negligence', $12^{\text {th }}$ December 2014, https://wanderingteacake.wordpress.com/the-saatchibill-2/theres-negligence/. See also tweets by the Bill's Twitter feed, which have for example claimed that '[d]octors will always have to justify their actions in court in the same way that they do now', (https://twitter.com/SaatchiBill/status/542367002376273920), both last accessed 4 ${ }^{\text {th }}$ July 2015.

${ }^{122}$ See D. Hills and J. Miola, 'The Saatchi Bill is Internally Inconsistent and Must Be Scrutinised in the Commons' $24^{\text {th }}$ February 2015, OpenDemocracy 
( http://webcache.googleusercontent.com/search?q=cache:gIYEST9RuB0J:https://www.opendemocrac y.net/ourkingdom/david-hills-jos\%25C3\%25A9-miola/saatchi-bill-is-internally-inconsistent-and-mustbe-scrutinised-in $+\& c d=1 \&$ hl=en\&ct=clnk\&gl=uk\&client=safari, last accessed $4^{\text {th }}$ June 2015).

${ }^{123}$ This was the view put forward by Robert Francis QC in his response to the DoH consultation (http://www.serjeantsinn.com/ImageLibrary/Medical\%20Innovation\%20Bill.pdf, last accessed $4^{\text {th }}$ July 2015). See his answer to question 8.

124 'Why Ebola Has Parallels With the MIB', http://medicalinnovationbill.co.uk/ebola-treatmentparallels-medical-innovation-bill/ (last accessed $4^{\text {th }}$ June 2015).

${ }^{125}$ See M. Evans, 'Ebola in Britain: Nurse Pauline Cafferkey Treated With Experimental Drug and Blood From a Survivor', Daily Telegraph, $31^{\text {st }}$ December 2014, http://www.telegraph.co.uk/news/worldnews/ebola/11319470/Ebola-nurse-Pauline-Cafferkey-treatedwith-blood-from-a-survivor.html (last accessed 4th June 2015).

${ }^{126}$ Ibid.

${ }^{127}$ Clark v Maclennan [1983] 1 All ER 416. See also M. Saatchi, 'A Law to Cure Cancer', The Spectator, 14 ${ }^{\text {th }}$ May 2014, http://health.spectator.co.uk/a-law-to-cure-cancer/, last accessed $4^{\text {th }}$ July 2015 .

${ }^{128}$ MIB s.1(2).

${ }^{129}$ A quack can be defined as someone who has no medical skills or knowledge but is a pretender to such skills or knowledge. This was the definition adopted by a report commissioned by the GMC: see H. de Vries, P. Sanderson et al, International Comparison of Ten Medical Regulatory Systems (Santa Monica, Rand, 2009), p64.

${ }^{130}$ This is the view of Sarah Wollaston MP, former chair of the Health Select Committee (see S. Faroqui, ‘Saatchi Bill A Quacks' Charter - Wollaston', PoliticsHome, $12^{\text {th }}$ December 2014, https://www.politicshome.com/health-and-care/articles/story/saatchi-bill-quacks-charter---wollaston, last accessed $4^{\text {th }}$ July 2015.

${ }^{131}$ For a recent example see A. Howarth, 'Expert Clinics Offering "Integrative Therapy” for Cancer if Saatchi Bill Passes', The Guardian $3^{\text {rd }}$ December 2014, http://www.theguardian.com/science/blog/2014/dec/03/clinics-integrative-therapy-cancer-saatchimedical-innovations-bill (last accessed 6th June 2015). 
${ }^{132}$ Medical Board of Australia v Boyd [2013] WASAT 123. I am grateful to Assoc Prof Tina Cockburn for bringing this case to my attention.

${ }^{133} \mathrm{Ibid}$, para 2.

${ }^{134}$ See AoMRC, 'Briefing on Medical Innovation Bill', 24 $4^{\text {th }}$ October 2014,

http://www.wellcome.ac.uk/stellent/groups/corporatesite/@policy_communications/documents/web_d ocument/wtp057760.pdf, last accessed $4^{\text {th }}$ July 2015.

${ }^{135}$ N. Poole, 'The Medical Innovation Register', above n79. 